\title{
Application of Shariah Enterprise Theory on Disclosure of Corporate Social Responsibility in Sharia Banking
}

\author{
Eti Kusmiati*, Marti Dewi Ungkari \\ Fakultasi Ekonomi, Universitas Garut, Indonesia \\ *corresponding author e-mail : etikusmiati@uniga.ac.id
}

\begin{tabular}{ll}
\hline Article Info & Abstract \\
& The goal of this research is to find out what information Islamic \\
Keywords: & banks provide in their corporate social responsibility reports, as \\
Corporate Social Responsibility; & well as to determine the acceptability of such material in terms of \\
Sharia Enterprise Theory; & Shariah Enterprise Theory (SET). This study employed a \\
Disclosure; & qualitative research method using a case study methodology. \\
Sharia Banking. & Primary and secondary data are the two types of data used. Data \\
\hline \multirow{2}{*}{ DOI: } & reduction, data presentation, and verification are some of the data \\
$10.33830 /$ elqish.v1i1.1453.2021 & processing strategies employed. Findings. The findings of the \\
& research demonstrate that Bank Muamalat's CSR disclosures \\
& contained Sharia Enterprise Theory disclosure elements such as \\
& vertical and horizontal accountability, indicating that Bank \\
& Muamalat Indonesia has declared its social responsibility in a very \\
& informative manner. \\
\hline
\end{tabular}

\section{Introduction}

The implementation of Corporate Social Responsibility (CSR) at the global level has received a positive response since the release of ISO 26000 in early November 2010 regarding Guidance on Social Responsibility. This in the end has made many parties aware that social responsibility is not merely a corporate obligation, but has become the responsibility of all parties, both institutions and private, individuals and entities, organizations that seek profit or call themselves non-profit (Pramiana \& Anisah, 2018).

In the current context of Indonesia, the implementation of CSR can be viewed from two perspectives. First, the implementation of CSR is a voluntary business practice, meaning that the implementation of CSR mostly comes from company initiatives and is not an activity that is required to be carried out by the company by the laws and regulations in force in the Republic of Indonesia. Second, CSR is no longer a discretionary business practice (voluntarily) but its implementation is regulated by law (Solihin, 2009). In the second perspective, CSR is based on the Law of the Republic of Indonesia Number 40 of 2007 concerning Perseroan Terbatas (PT). This is stated in article 74 paragraph (1) that "Perseroan Terbatas that run businesses in the field and/or are concerned with natural resources are obliged to carry out social and environmental responsibilities".

Corporate Social Responsibility is a business commitment to contribute to sustainable economic development, working with employees, their families, local communities, and society in general to improve their quality of life (World Business Council for Sustainable Development, 2003). Corporate Social Responsibility is the way companies manage and improve their social and environmental impacts to generate value for shareholders and stakeholders by innovating strategies, organizations, and operations (Farag, Mallin, \& Ow-yong, 2014). The CSR concept integrates three dimensions: the economic dimension (efficiency, profitability), the social dimension (social responsibility), and the environmental dimension (environmental responsibility) (Belkacem \& Ladraa, 2015; Platonova, Asutay, Dixon, \& Mohammad, 2018). 
CSR reporting is a process of communicating the social and environmental impacts of an organization's economic actions on certain community groups and society as a whole (Platonova et al., 2018; Farag et al., 2014). Expanding the accountability of an organization into the scope of CSR reporting, not just presenting financial accounts for shareholders. This expansion is based on the assumption that corporate responsibility is not limited to generating profits for shareholders, but is broader than that, including responsibilities to society and the universe. (Alamer, Salamon, Qureshi, \& Rasli, 2015; Muhamat, Jaafar, \& Basri, 2017).

In line with the concept of CSR, the Law of the Republic of Indonesia Number 21 of 2008 concerning Islamic Banking confirms the social function of Islamic banks. This statement can be examined in article 4 which states that in addition to being obliged to carry out the function of financial intermediation, Islamic banks and Sharia Business Units (UUS) can carry out social functions in the form of baitul mal institutions, namely collecting funds from zakat, infaq, alms, grants, or other social funds and distribute them to zakat management organizations. In Article 4, it is also stated that Islamic banks can collect social funds originating from cash waqf and distribute them to waqf managers (nazhir) following the will of the waqf giver (wakif).

Standard CSR reporting and measurement standards for Islamic business institutions are not yet available (Ridwan \& Mayapada, 2020; Devirahtiasari, Fitrarahmasari, \& Fadah, 2018). As a result, Islamic companies and business institutions still adopt conventional corporate CSR reporting standards in reporting their CSR activities (Trianaputri, Siswantoro, \& Dewi, 2017). Likewise with PT. Bank Muamalat Indonesia, which uses the Global Reporting Index (GRI) G4 Index as a standard in reporting and measuring CSR. Although in principle, this index cannot be used in Islamic business institutions. The GRI index is an index used by conventional banks that contains matters that are in principle contrary to Islamic principles, namely disclosure of usury, gharar, zakat, and other Islamic values (Shahabuddin, Alamer, Sukor, \& Naseem, 2018). The nonfulfillment of sharia rules/indexes on the disclosure of sharia corporate social responsibility has an impact on the misalignment between the disclosure of Islamic/sharia-based corporate social responsibility with something that is the reference, in this case, the sharia-based social responsibility disclosure index (Nor \& Hashim, 2015; Farag et al., 2014).

Along with the rapid development of sharia institutions, in recent years several Islamic economists have initiated specific forms of social performance reporting for sharia business institutions, one of which is Shariah Enterprise Theory (SET) (Nasim \& Solihati, 2019; Putra \& Wijayanti, 2020). In SET, the important concept is Allah as the Creator and Sole Owner of all the resources in this world, then Allah as the main Trust Giver. Meanwhile, the resources owned by the stakeholders are, in principle, a mandate from God in which there is a responsibility to use them in the manner and purpose set by the Trustee (Aryani \& Zuchroh, 2018; Meldona, Riska, Rochayatun, \& Nurdin, 2020; Musthafa, Triyuwono, \& Adib, 2020). In other words, Sharia Enterprise Theory has a broader vision, which appears in the breadth of the scope of the company's stakeholders. According to this theory, stakeholders include direct and indirect participants, which are different from direct and indirect participants in enterprise theory.

The SET index in the disclosure of corporate social responsibility, especially Islamic banking, has several dimensions, namely vertical accountability and horizontal accountability. Vertical accountability is a corporate social responsibility that is aimed only at Allah SWT. In the SET index, vertical accountability is manifested in the opinion of the Sharia Supervisory Board regarding the disclosure of fatwas and operational aspects that are complied with and not complied with along with the reasons. While horizontal accountability is a corporate social responsibility to three parties, namely: direct stakeholders, indirect stakeholders, and nature. According to SET, the so-called direct stakeholders are customers and employees. Meanwhile, according to SET, the 
parties included as indirect stakeholders are the community (Meutia, 2010; Putra \& Wijayanti, 2020).

Research conducted by Ridwan \& Mayapada (2020) shows that the disclosure of social responsibility by Islamic commercial banks in Indonesia is still voluntary and several items do not quite meet the sharia index which refers to the Sharia Enterprise Theory (SET). The most appropriate theory to reveal corporate social responsibility (in this case Islamic banks) is SET, because it is considered to have dimensions that include Vertical Accountability and Horizontal Accountability (Meutia, 2010; Saleh, Sulistyo, Hisamuddin, \& Roziq, 2018). Based on the description above, this article intends to analyze the disclosure of Corporate Social Responsibility (CSR) based on Shariah Enterprise Theory (SET).

\section{Research Method}

This is a qualitative study using a case study technique. PT Bank Muamalat Indonesia is the subject of this investigation. Secondary data was acquired from data that was published on Bank Muamalat Indonesia's official website, such as the annual report and Bank Muamalat's sustainability report for 2014-2018. Interviews provided the primary data. The interviews were from the Bank Muamalat Garut Branch Office's Human Resources department. Interviews were performed in a systematic and planned way, with the author preparing a list of questions ahead of time.

The research variable in this study is CSR, which will be examined using the SET approach. The focus of this study is on documenting CSR activities in yearly reports, as well as analyzing and evaluating their applicability using the SET theory or idea. This analysis' particular description is as follows: (1) Identifying the disclosure elements according to Sharia Enterprise Theory (SET). The SET disclosure elements were adapted from Aryani and Zuchroh (2018) and Meldona et al. (2020), who designed them based on two levels of accountability: vertical and horizontal accountability. (2) Performing the scoring. If things are disclosed, they are given a score of 1 (one), and if no items are released, they are given a value of 0 (zero); (3) Conduct analysis and evaluation; and (5) Provide a conclusion, in which the disclosure score is grouped into four categories:

Table 1. Predicate Level of CSR Disclosure of Islamic Banks

\begin{tabular}{ll}
\hline Predicate & Index Value \\
\hline Very Informative & $81-100$ \\
Informative & $66-80$ \\
Less Informative & $51-65$ \\
Not Informative & $0-50$ \\
\hline
\end{tabular}

Source: Gustani dan Bayinah (2014)

The analysis is carried out by assigning a score or value to each disclosure item, totaling 46 . Then, calculate the percentage of each SET sub-item/dimension. The formula used to calculate the percentage for each disclosure item is as follows:

$$
\boldsymbol{S E T}=\frac{\text { Number of points disclosured }}{\text { Total score } \max } \times 100 \%
$$




\section{Results and Discussions}

\section{CSR Disclosure Based on SET Indeks Index}

The following are the results of Bank Muamalat's SET index scoring from 2014 to 2018, based on the dimensions or sub-items of SET disclosure, which include vertical accountability to the National Sharia Board (DSN) and Sharia Supervisory Board (DPS), as well as horizontal accountability to direct and indirect stakeholders, such as customers and employees.

Table 2. CSR Disclosure Based on SET Indeks Index

\begin{tabular}{llllllll}
\hline No & Sub-Item Disclosure & $\mathbf{2 0 1 4}$ & $\mathbf{2 0 1 5}$ & $\mathbf{2 0 1 6}$ & $\mathbf{2 0 1 7}$ & $\mathbf{2 0 1 8}$ & Average \\
\hline \multirow{2}{*}{$\begin{array}{l}\text { National Sharia Board \& } \\
\text { Sharia Supervisory Board }\end{array}$} & $100 \%$ & $100 \%$ & $100 \%$ & $100 \%$ & $100 \%$ & $100 \%$ \\
2 & Customer & $70,59 \%$ & $88,24 \%$ & $88,24 \%$ & $88,24 \%$ & $82,35 \%$ & $83,53 \%$ \\
3 & Employee & $100 \%$ & $100 \%$ & $100 \%$ & $100 \%$ & $100 \%$ & $100 \%$ \\
4 & Community & $100 \%$ & $88,89 \%$ & $88,89 \%$ & $66,67 \%$ & $66,67 \%$ & $82,22 \%$ \\
5 & Environment & $37,5 \%$ & $50 \%$ & $62,5 \%$ & $37,5 \%$ & $37,5 \%$ & $45 \%$ \\
\hline
\end{tabular}

The greatest score gained by vertical responsibility to DSN and DPS, as well as horizontal accountability to workers, is 100 percent, as shown in Table 2. On the other hand, horizontal accountability to nature received the lowest score of 45 percent. The results of the vertical accountability scoring are consistent with the findings of interviews, which show that DPS has an impact, particularly on product development at BMI, which is determined through a debate process between the Board of Directors and the Sharia Supervisory Board. While the results of interviews on the horizontal accountability component to employees revealed that BMI has a very effective system, namely Muamalat Human Power, which checks the facilities obtained by employees using the NIK of each employee to make it easier for employees to use the company's facilities.

\section{Vertical Accountability}

The vertical accountability assessment consists of 2 assessment items, namely the opinion of the Sharia Supervisory Board (DPS) and reporting on compliance with the fatwa in the operational aspects of sharia banking. The table of scoring results on vertical accountability: DSN and DPS can be seen in Table 3 below:

Table 3. Vertical Accountability

\begin{tabular}{|c|c|c|c|c|c|}
\hline Items Disclosure & 2013 & 2014 & 2015 & 2016 & 2017 \\
\hline $\begin{array}{l}\text { 1. Sharia Supervisory Board (DPS) } \\
\text { Opinion }\end{array}$ & 1 & 1 & 1 & 1 & 1 \\
\hline $\begin{array}{l}\text { 2. Using fatwas and operational aspects } \\
\text { that are complied with and not complied } \\
\text { with and the reasons }\end{array}$ & 1 & 1 & 1 & 1 & 1 \\
\hline $\begin{array}{c}\text { Total } \\
\text { Percentage }(\%)\end{array}$ & $\begin{array}{l}2 \\
100\end{array}$ & $\begin{array}{l}2 \\
100\end{array}$ & $\begin{array}{l}2 \\
100\end{array}$ & $\begin{array}{l}2 \\
100\end{array}$ & $\begin{array}{l}2 \\
100\end{array}$ \\
\hline
\end{tabular}

Source: BMI Annual Report - Reprocessed data 
Sharia Enterprise Theory in the context of Vertical Accountability is the opinion of the Sharia Supervisory Board and the disclosure of fatwas and operational aspects that are complied with and not complied with along with the reasons. The report of the Sharia Supervisory Board, in this case, provides a guarantee that the operations and products of Islamic banks are following the fatwa of the National Sharia Council (DSN) - the Indonesian Ulema Council, and the Opinion of the DPS.

The results showed that the results of calculating the vertical accountability dimension index score, PT Bank Muamalat Indonesia (BMI), which was the object of this study, got the maximum value, which was $100 \%$ in the 2013-2017 period. This means that DPS BMI always reminds BMI to consistently make efforts to improve some operational aspects that still need to be perfected following sharia principles. The results of this scoring are evidenced by the results of interviews which state that the opinion of DPS has an effect, especially in product development, which must be carried out through the process of meeting the power director with DPS BMI. This means that all products issued by BMI are following the opinion of the DPS and the fatwa it has issued. The new product development process is usually reviewed by the relevant function first, then submitted for opinion/approval from the DPS. Furthermore, DPS will discuss the fatwa regarding the product following the Fatwa of the National Sharia Council-MUI. If there is no completeness and incompatibility with the fatwa, the DPS proposes to the Bank's Directors to complete the new product contract so that it is operationally following the fatwa of the DSN-MUI. So that it can be said that Bank Muamalat has seriously tried to fulfill the principle of compliance with sharia fatwas both in product and operational aspects and disclosed it in the Annual Report. The results of the interview also confirm the research findings that the DPS technically does not understand the process of creating a sustainable economy in-depth, due to the narrow scope of duties and functions of the DPS, which is only as an internal supervisor. Thus, the influence of the contribution of DPS on CSR activities is also not too large. This is reinforced by the fact that there are BMI subsidiaries that are directly responsible for handling BMI's CSR programs.

\section{Horizontal Accountability: Direct Stakeholders}

There are seventeen points of Sharia Enterprise Theory assessment in the context of Horizontal Accountability on the customer component, ten points on the employee component. The following describes the scoring results on the horizontal accountability sub-item - customers and employees: 
Table 4. Horizontal Accountability Direct Stakeholders

\begin{tabular}{|c|c|c|c|c|c|}
\hline Items Disclosure & 2013 & 2014 & 2015 & 2016 & 2017 \\
\hline \multicolumn{6}{|l|}{ Customer } \\
\hline 1. Qualifications and experience of DPS members & 1 & 1 & 1 & 1 & 1 \\
\hline Activities carried out by DPS members & 1 & 1 & 1 & 1 & 1 \\
\hline Remuneration for DPS members & 1 & 1 & 1 & 1 & 1 \\
\hline $\begin{array}{l}\text { 4. Whether or not there are transactions/sources of income/costs } \\
\text { that are not sharia-compliant }\end{array}$ & 1 & 1 & 1 & 1 & 1 \\
\hline The number of transactions that are not sharia-compliant & 1 & 1 & 1 & 1 & 1 \\
\hline The reason for the transaction & 1 & 1 & 1 & 1 & 0 \\
\hline Product information and the underlying sharia concept & 1 & 1 & 1 & 1 & 1 \\
\hline Report on zakat funds and qardhul hasan & 0 & 1 & 1 & 1 & 1 \\
\hline 9. Audit of zakat and qardhul hasan reports & 0 & 1 & 1 & 1 & 1 \\
\hline 10. Explanation of the source and use of zakat funds & 1 & 1 & 1 & 1 & 1 \\
\hline 11. Explanation of the source and use of qardhul hasan funds & 1 & 1 & 1 & 1 & 1 \\
\hline 12. Explaining the recipient of qardhul hasan funds & 0 & 1 & 1 & 1 & 1 \\
\hline 13. Policies/efforts to reduce non-sharia transactions in the future & 0 & 0 & 0 & 0 & 0 \\
\hline $\begin{array}{l}\text { 14. The amount of financing with the Profit Loss Sharing (PLS) } \\
\text { scheme }\end{array}$ & 1 & 1 & 1 & 1 & 1 \\
\hline 15. Percentage of PLS financing compared to another financing & 1 & 1 & 1 & 1 & 1 \\
\hline Policies/efforts to enlarge the portion of PLS in the future. & 0 & 0 & 0 & 0 & 0 \\
\hline Reasons for the amount of financing under the PLS scheme & 1 & 1 & 1 & 1 & 1 \\
\hline Total & 12 & 15 & 15 & 15 & 14 \\
\hline Percentage (\%) & 70,59 & 88,24 & 88,24 & 88,24 & 82,35 \\
\hline \multicolumn{6}{|l|}{ Employee } \\
\hline 1. Wage and remuneration policy & 1 & 1 & 1 & 1 & 1 \\
\hline $\begin{array}{l}\text { 2. Disclosure of non-discrimination policies applied to employees } \\
\text { in terms of wages, training, career advancement opportunities }\end{array}$ & 1 & 1 & 1 & 1 & 1 \\
\hline Providing training and education to employees & 1 & 1 & 1 & 1 & 1 \\
\hline Employee data and composition & 1 & 1 & 1 & 1 & 1 \\
\hline The amount of training and education provided to employees & 1 & 1 & 1 & 1 & 1 \\
\hline Appreciation to employees & 1 & 1 & 1 & 1 & 1 \\
\hline Training related to improving the quality of employees & 1 & 1 & 1 & 1 & 1 \\
\hline 8. Efforts to improve the spiritual quality of employees' families & 1 & 1 & 1 & 1 & 1 \\
\hline $\begin{array}{l}\text { 9. Availability of health services and counseling for employees } \\
\text { and their families }\end{array}$ & 1 & 1 & 1 & 1 & 1 \\
\hline $\begin{array}{l}\text { 10. Other facilities provided to employees and their families such } \\
\text { as scholarships and special financing }\end{array}$ & 1 & 1 & 1 & 1 & 1 \\
\hline Total & 10 & 10 & 10 & 10 & 10 \\
\hline Percentage (\%) & 100 & 100 & 100 & 100 & 100 \\
\hline
\end{tabular}

Source: BMI Annual Report - Reprocessed data

The results show that in the period 2013-2017, of the 17 disclosure items in the SET index, 11 items have been fully implemented following the CSR disclosure items based on the Sharia Enterprise Theory (SET). Among them, in terms of increasing customer confidence in the qualifications of DPS members, BMI has disclosed the qualifications, experience, activities, and remuneration of DPS members. Currently, 3 DPS BMI members are consisting of 1 DPS chairman 
and 2 DPS members. The three DPS members have extensive experience in the field of sharia and have long been members of the DPS in several banks/non-bank financial institutions. The amount of compensation given to DPS is also detailed in BMI's Financial Statements. The results of interviews regarding matters relating to the qualifications of DPS members indicate that there are separate policies from the management of BMI through discussions with stakeholders by considering their expertise, expertise, experience, and achievements.

Other scoring results show that in 2013-2017 BMI revealed the existence of transactions/sources/costs of income that were not following sharia, namely the existence of nonhalal income and the reasons for it. However, in 2017 BMI did not disclose the reasons for nonsharia income. This results in a reduced score, which means that there are incomplete CSR disclosure items based on the Sharia Enterprise Theory (SET). The scoring results are reinforced by the results of interviews which state that BMI does not allow non-halal transactions, but in reality, there are income costs that come from non-sharia sources such as ta'zir. Ta'zir can be likened to a fine in a conventional bank. Ta'zir occurs because there is a customer delay in fulfilling their obligations and is done intentionally.

The annual report states that the non-halal income in question is funding from conventional bank interest income. This fund represents interest received from BMI accounts at conventional banks participating in the ATM Bersama network. In addition to funds from conventional bank interest income, there are still fines (ta'zir), where this fine (ta'zir) is a fine for delays in payments from intentional debtors. Furthermore, all the funds will be used for social purposes. BMI stated that Non-ZIS (Zakat Infaq Shodaqoh) funds cannot be utilized for educational purposes and worship facilities. For this reason, non-ZIS funds are used for the construction and repair of public facilities. Such as the construction of MCK, clean water facilities, the Go Green campaign, the construction of hospitals, and other social activities.

This is following the results of interviews between researchers with related parties that regarding transactions/sources/costs of income that are not following sharia Bank Muamalat does not allow non-halal transactions, but in reality, there are non-sharia income costs, such as ta'zir. it happened because there were customers who were late in paying the contract and it was done on purpose, so inevitably they were exposed to ta'zir or fines, the same thing with conventional banks, the only difference is that it depends on the contract.

The next item is about financing with the Profit Loss Sharing (PLS) scheme, the item has been disclosed by BMI along with the reasons for the amount of the financing and the percentage comparison with other financings. Bank Muamalat distributes financing facilities to customers for productive and consumptive purposes, which are recorded based on the contract or the scheme used, namely as sale and purchase receivables, Qardh loans, Mudharabah financing, Musyarakah financing, and Ijarah. As for policies or efforts to increase the portion of PLS in the future, the scoring results show $0 \%$ during the period 2013-2017, which means that there is no disclosure on this item. From the interview results, it is known that related to financing, BMI has its policy issued directly by the head office which sets different targets for each branch of BMI, and is carried out quarterly so that the strategies adopted will be different in each branch. This is the reason why the item "Policies/efforts to increase the portion of PLS in the future" is not disclosed in the BMI annual report.

The results of the SET index scoring on Direct Stakeholders: Employees show optimal scores. This means that the development of SDI in BMI has fulfilled all SET index items. BMI has disclosed all items related to employees as described in the Sharia Enterprise Theory (SET) which relates to wage and remuneration policies, policies regarding equality of opportunity, availability 
of counseling and health services as well as several facilities provided by the company to employees and their families.

The scoring results are reinforced by the results of interviews which explain that BMI has a very effective system, namely Muamalat Human Power which is very useful for all employees to check benefits, salary slips, leave permits, and others by using the NIK of each employee so that it can make it easier for employees to use facilities provided by the company. BMI also ensures that every employee has adequate competence with their work demands through the implementation of various training to improve knowledge \& skills and improve the spiritual quality of each employee. Every employee who excels is always given a reward, and every month a competency test is always held to assess the extent of the employee's ability to the training provided.

\section{Horizontal Accountability: Indirect Stakeholders}

Bank Muamalat Indonesia's Social Responsibility (CSR) activities in the field of social community development are grouped into programs aimed at supporting community economic development, education programs, and humanitarian aid programs. Meanwhile, Bank Muamalat's CSR program in environmental aspects is carried out in several activity programs such as the Muamalat Response Action, the Muamalat Healthy Action, and the construction of the Water Tower. Several other activities are routinely carried out, namely the Go Green campaign, Green Campaign, tree planting, clean water sanitation programs, and others. The following is a table of scoring results for Horizontal - Indirect Stakeholders: Community and Nature accountability based on the SET index in 2013-2017: 
Table 5. Horizontal Accountability Indirect Stakeholders

\begin{tabular}{|c|c|c|c|c|c|}
\hline Items Disclosured & 2013 & 2014 & 2015 & 2016 & 2017 \\
\hline \multicolumn{6}{|l|}{ Community } \\
\hline $\begin{array}{l}\text { 1. Initiatives to increase public access to Islamic bank } \\
\text { financial services }\end{array}$ & 1 & 1 & 1 & 1 & 1 \\
\hline $\begin{array}{l}\text { 2. A financing policy that takes into account discrimination } \\
\text { and human rights issues (for example, not financing } \\
\text { companies or businesses that employ minors) }\end{array}$ & 1 & 0 & 0 & 0 & 0 \\
\hline $\begin{array}{l}\text { 3. A financing policy that considers the interests of the } \\
\text { community at large }\end{array}$ & 1 & 1 & 1 & 1 & 1 \\
\hline 4. Efforts made to encourage the development of MSMEs & 1 & 1 & 1 & 0 & 0 \\
\hline 5. The amount of financing provided to MSMEs & 1 & 1 & 1 & 0 & 0 \\
\hline $\begin{array}{l}\text { 6. Amount and percentage of financing provided to } \\
\text { customers }\end{array}$ & 1 & 1 & 1 & 1 & 1 \\
\hline $\begin{array}{l}\text { 7. Contribution to improve people's quality of life in the } \\
\text { fields of religion, education, health. }\end{array}$ & 1 & 1 & 1 & 1 & 1 \\
\hline 8. Amount of contributions made and their sources & 1 & 1 & 1 & 1 & 1 \\
\hline $\begin{array}{l}\text { 9. Donations/alms to help community groups affected by } \\
\text { disasters }\end{array}$ & 1 & 1 & 1 & 1 & 1 \\
\hline Total & 9 & 8 & 8 & 6 & 6 \\
\hline Percentage $(\%)$ & 100 & $\mathbf{8 8 , 8 9}$ & $\mathbf{8 8 , 8 9}$ & 66,67 & 66,67 \\
\hline \multicolumn{6}{|l|}{ Environment } \\
\hline $\begin{array}{l}\text { 1. A financing policy that considers environmental issues } \\
\text { such as energy-saving, forest destruction, water, and air } \\
\text { pollution }\end{array}$ & 1 & 1 & 1 & 1 & 1 \\
\hline $\begin{array}{l}\text { 2. Disclosure if there is financing provided to businesses } \\
\text { that have the potential to damage the environment such } \\
\text { as plantations, forestry, and mining }\end{array}$ & 0 & 0 & 0 & 0 & 0 \\
\hline $\begin{array}{l}\text { 3. The amount of financing for businesses that have the } \\
\text { potential to damage the environment, such as plantations, } \\
\text { forestry, and mining. }\end{array}$ & 0 & 0 & 0 & 0 & 0 \\
\hline 4. Reasons for doing the financing & 0 & 0 & 0 & 0 & 0 \\
\hline $\begin{array}{l}\text { 5. Increase environmental awareness to employees with } \\
\text { training, lectures, or similar programs. }\end{array}$ & 1 & 1 & 1 & 1 & 1 \\
\hline $\begin{array}{l}\text { 6. Bank's internal policies that support energy-saving and } \\
\text { conservation programs. }\end{array}$ & 0 & 0 & 1 & 1 & 1 \\
\hline $\begin{array}{l}\text { 7. Contribution to organizations that provide benefits to } \\
\text { environmental conservation. }\end{array}$ & 0 & 1 & 1 & 0 & 0 \\
\hline $\begin{array}{l}\text { 8. Direct contribution to the environment (planting trees, } \\
\text { etc.) }\end{array}$ & 1 & 1 & 1 & 0 & 0 \\
\hline Total & 3 & 4 & 5 & 3 & 3 \\
\hline Percentage (\%) & 37,5 & 50 & 62,5 & $\mathbf{3 7 , 5}$ & 37,5 \\
\hline
\end{tabular}

Source: BMI Annual Report - Reprocessed data

Table 5 shows that of the 9 items of disclosure of Horizontal Indirect Stakeholders Accountability: Community based on SET, there are 6 items of social responsibility disclosure that have been disclosed by BMI during the period 2013-2017. One of the items that were not 
disclosed was regarding policies that consider issues of discrimination and human rights. Only in 2013, the item was disclosed so that BMI obtained a score of $100 \%$ for its disclosure item. In the 2013 Annual Report, it is stated that throughout 2013, Bank Muamalat collaborated with several other institutions in carrying out CSR activities and one of them was the International Organization under the auspices of the United Nations which specifically provided humanitarian assistance for children (UNICEF). This is reinforced by the results of interviews which stated that BMI no longer cooperated with institutions engaged in dealing with issues of discrimination and human rights in 2014-2017, so there were no things/activities that could be reported and disclosed. However, this does not affect the CSR disclosure of BMI. This is in line with the observations in BMI's financial statements that every year they always carry out similar activities, with various themes.

Horizontal Indirect Stakeholders Accountability Disclosure from the perspective of Environment, from 8 disclosure items, there are only 2 disclosure items made by BMI in the 20132017 range, namely financing policies that consider environmental issues such as energy-saving, forest damage, water, and air pollution; and increase environmental awareness among employees through training, lectures, or similar programs. Items that have not been disclosed during the 20132017 period, namely related to financing provided to businesses that have the potential to damage the environment and the amount, are not disclosed in the annual report because BMI does not finance businesses that have the potential to damage the environment. This is reinforced by the results of interviews which stated that BMI did not provide financing related to negative things. This is closely related to the working principle of BMI which is based on Islamic law. BMI's business operations must be clean of things that are not following sharia principles and follow policies that are following sharia principles. This is what causes the disclosure value on several Horizontal Accountability: Environment items to be $0 \%$.

The score, percentage value, and predicate of Bank Muamalat Indonesia's CSR disclosure level were calculated using the SET scoring results from 2014 to 2018, as given in table 6 below:

Table 6. Level of Disclosure and Predicate of CSR Disclosure Based on SET 2014-2018

\begin{tabular}{lllll}
\hline No & Year & $\begin{array}{l}\text { Number of Items } \\
\text { Disclosure }\end{array}$ & Disclosure Rate & Predicate \\
\hline 1 & 2014 & 36 & $78 \%$ & Informative \\
2 & 2015 & 39 & $85 \%$ & Very Informative \\
3 & 2016 & 40 & $87 \%$ & Very Informative \\
4 & 2017 & 36 & $78 \%$ & Informative \\
5 & 2018 & 35 & $76 \%$ & Informative \\
& & Rata-rata & $81 \%$ & Very Informative \\
\hline
\end{tabular}

Source: BMI Annual Report-Reprocessed data

In 2014, the predicate of CSR disclosure based on SET on BMI was predicated as informative, with a disclosure rate of 78 percent, according to table 6 . This signifies that throughout the year 2013, BMI engaged in CSR initiatives, which were reported in the company's annual report. According to the SET index, BMI has supplied information (disclosure) on 78 percent of the 46 disclosure elements (vertical and horizontal accountability) in the SET index, or around 36 items.

BMI made the most disclosures in 2016, with 87 percent or 40 items out of a total of 46 SET index items, and the least in 2018, with 76 percent or 35 items out of a total of 46 SET index items. 
Overall, the average BMI disclosure rate was 81 percent from 2014 to 2018, indicating that BMI has revealed its social responsibilities in a fairly transparent manner.

CSR activities not only affect the surrounding community but have a positive impact on the company's reputation. The findings of this study are not much different from the research conducted by Platonova et al. (2018) which examines the relationship between corporate social responsibility (CSR) and financial performance for Islamic banks, Aryani \& Zuchroh (2018) examines the effect of GCG, ROE on CSR, and Ridwan \& Mayapada (2020) which examines the influence of governance sharia on the disclosure of corporate social responsibility in Islamic banks in Indonesia. The difference between these studies and this research is that this study does not directly link CSR with company performance, but rather explores the components of CSR disclosure according to SET.

If the research above focuses more on the importance of disclosure of corporate social responsibility (CSR) related to company performance and sustainability. This study provides an explanation of the relevance of CSR disclosure using Sharia Enterprise Theory (SET). As done by Aryani and Zuchroh (2018) who researched the implementation of CSR in Islamic banks based on Sharia Enterprise Theory which was carried out on ten Islamic banks in Indonesia; Nor \& Hashim (2015) explore the dimensions of social responsibility and sustainability of Islamic banking in Malaysia from a management point of view, and Meutia (2010) examined how to develop the concept and characteristics of social responsibility disclosure and Islamic bank social responsibility disclosure items.

Furthermore, this study found the suitability of the findings with research conducted by Ridwan \& Mayapada, 2020; Devirahtiasari, Fitrarahmasari, \& Fadah, (2018) who explained that the SET index can disclose company reports more comprehensively, so that it can be used as a reference for reporting Islamic institutions, which until now still adopt conventional corporate CSR disclosure systems, as well as research conducted by Alamer, Salamon, Qureshi, \& Rasli, 2015; Muhamat, Jaafar, \& Basri, (2017) which explains that corporate responsibility is not limited to generating profits for shareholders, but is broader than that, which includes vertical and horizontal responsibilities.

\section{Conclusions}

Based on the findings of research conducted on PT Bank Muamalat Indonesia's Annual Report, it can be concluded that PT Bank Muamalat Indonesia's disclosure of Corporate Social Responsibility (CSR) included Sharia Enterprise Theory (SET) disclosure items, namely vertical and horizontal accountability, consisting of direct and indirect stakeholders (customers and employees) (community and nature). Vertical accountability and horizontal accountability to workers were the only disclosure categories that received a perfect score of 100 percent from 2014 to 2018. Meanwhile, horizontal accountability to nature receives the lowest grade, with an average of 45 percent. In 2014-2018, the average proportion of corporate social responsibility (CSR) disclosure was 81 percent, with a very informative predicate. Because most of the disclosure items in the SET index are in the SET index, this demonstrates that PT Bank Muamalat Indonesia has revealed its social responsibility in a fairly informal manner. 


\section{References}

Alamer, A. R. A., Salamon, H. Bin, Qureshi, M. I., \& Rasli, A. M. (2015). CSR's Measuring Corporate Social Responsibility Practice in Islamic Banking: A Review. International Journal of Economics and Financial Issues, 5, 198-206.

Aryani, D. N., \& Zuchroh, I. (2018). GCG , ROE and Size on CSR Based on Sharia Enterprises Theory. Tazkia Islamic Finance and Business Review, 12(1), 61-80.

Belkacem, M., \& Ladraa, K. (2015). The role of Islamic banks in the establishment of social responsibility within Islamic Countries. Journal of Emerging Issues in Economics, Finance and Banking (JEIEFB), 4(1), 1377-1384.

Devirahtiasari, Fitrarahmasari, R., \& Fadah, I. (2018). CSR In Islamic Perspective. International Journal Of Scientific \& Technology Research, 7(12), 50-53.

Farag, H., Mallin, C., \& Ow-yong, K. (2014). Corporate Social Responsibility and Financial Performance in Islamic Banks. Journal of Economic Behavior and Organization, 1-42. https://doi.org/10.1016/j.jebo.2014.03.001

Gustani, \& Bayinah, A. n. (2014). Model pelaporan kinerja sosial perbankan syariah : implementasi islamic social reporting index (Index ISR) di indonesia. Jurnal Akuntansi dan keuangan Islam , 2 No. 1.

Meldona, Riska, N. A., Rochayatun, S., \& Nurdin, F. (2020). Corporate Social Responsibility Disclosure Through Sharia Enterprise Theory. In 3rd Asia Pacific International Conference of Management and Business Science (AICMBS 2019) (Vol. 135, pp. 171-179).

Meutia, I. (2010). The Concept of Social Responsibility Disclosures For Islamic Banks Based On Shari'ah Enterprise Theory. Jurnal Akuntansi Multiparadigma, 1(3), 369-382.

Muhamat, A. A., Jaafar, M. N., \& Basri, M. F. (2017). Corporate Social Performance (CSP) Influences on Islamic Bank's Financial Performance. Journal of International Business, Economics, and Entrepreneurship, 2(1), 11-16.

Musthafa, T. F., Triyuwono, I., \& Adib, N. (2020). Application Of Asset Revaluation By The Public Assessment Office : A Reflection Of Sharia Accounting, Shari'ah Enterprise Theory. International Journal of Economics, Business, and Accounting Research (IJEBAR), 4(3), 1626.

Nasim, A., \& Solihati, S. Y. (2019). Comparison Analysis of Sharia Banking Financial Performance Using Income Statement Approach and Value Added Statement Approach. In 1st International Conference on Economics, Business, Entrepreneurship, and Finance (Vol. 65, pp. 85-87).

Nor, S. M., \& Hashim, N. A. (2015). CSR and Sustainability of Islamic Banking: The Bankers View. Jurnal Pengurusan, 45, 1-16. https://doi.org/10.17576/pengurusan-2015-45-07

Platonova, E., Asutay, M., Dixon, R., \& Mohammad, S. (2018). The Impact of Corporate Social Responsibility Disclosure on Financial Performance: Evidence from the GCC Islamic Banking Sector. Journal of Business Ethics, 151(2), 451-471. https://doi.org/10.1007/s10551-016-3229-0

Pramiana, O., \& Anisah, N. (2018). Implementasi Corporate Social Responsibility (CSR) Dalam Perspektif Shariah Enterprise Theory. EKSIS, 13(2), 169-182.

Putra, R., \& Wijayanti, R. R. (2020). Islamic Values in the Annual Reports of the Shariah Bank to Create a Sharia Value-Added. Journal of Accounting and Investment, 21(1), 90-113. https://doi.org/10.18196/jai.2101139

Ridwan, R., \& Mayapada, A. G. (2020). Does sharia governance influence corporate social responsibility disclosure in Indonesia Islamic banks? Journal of Sustainable Finance \& 
Investment, 0(0), 1-20. https://doi.org/10.1080/20430795.2020.1749819

Saleh, M., Sulistyo, A. B., Hisamuddin, N., \& Roziq, A. (2018). Profit And Loss Sharing System and Profitability of Islamic Rural Bank in East Jawa Indonesia. The International Journal of Social Sciences and Humanities Invention, 5(09), 4986-4991. https://doi.org/10.18535/ijsshi/v5i9.06

Shahabuddin, A., Alamer, A. R. A., Sukor, M. E. A., \& Naseem, N. A. M. (2018). Weighted Corporate Social Responsibility Index for Measuring Islamic Banking's Social Performance : How to Develop It ? International Journal of Economics and Management, 12(1), 233-246.

Solihin, Ismail., (2009), Corporate Social Responsibility: From Charity to Sustainability, Salemba Empat, Jakarta.

Trianaputri, A. R., Siswantoro, D., \& Dewi, M. K. (2017). CSR in Islamic Financial Institution : A Literature Review. Tazkia Islamic Finance and Business Review, 11(2), 107-126. 